\title{
Pengaruh Pembelajaran Menggunakan Media Hullahop Terhadap Peningkatan Hasil Belajar Senam Lantai Pada Siswa Kelas VIII Di SMP Negeri 1 Pakusari
}

\author{
Dewi Irma Ristanti', Wawan Setiawan'²,Donny Setiawan ${ }^{3}$ \\ 1 Guru PJOK SDN 1 Gebang, Kabupaten Jember \\ 2,3 Prodi Pendidikan Jasmani Kesehatan dan Rekreasi, Universitas PGRI Banyuwangi \\ Email: dewiirma0410@gmail.com¹,wawan11setiawan11@gmail.com²
}

\begin{abstract}
ABSTRAK
Senam ini dikatakan sebagai aktivitas dasar dan menjelma dari setiap bagian anggota tubuh dari kemampuan komponen motorik atau gerak seperti kekuatan, kecepatan, keseimbangan, kelenturan, kelincahan, dan ketepatan. Salah satu contoh senam lantai adalah gerakan dengan melakukan guling depan dan guling belakang. Penelitian ini merupakan Penelitian Tindakan Kelas (action research). Tujuan yang ingin dicapai dalam penelitian ini adalah untuk meningkatkan pembelajaran senam lantai menggunakan media hulahoop. Subjek penelitian adalah siswa kelas VII SMP Negeri 1 Pakusari yang berjumlah 30 anak, terdiri atas siswa putra sebanyak 15 anak dan siswa putri sebanyak 15 anak. Instrumen dalam penelitian ini merupakan alat yang digunakan untuk mengungkap atau menggambarkan objek penelitian. Instrumen dalam penelitian ini adalah instrumen tes unjuk kerja guling depan. Dari hasil penelitian pembelajaran senam lantai guling depan dan guling belakang tersebut dapat disimpulkan bahwa tindakan pembelajaran senam lantai guling depan dan guling belakang menggunakan media hulahoop yang dilakukan dalam 2 siklus, terbukti mampu meningkatkan hasil pembelajaran pada siswa kelas VIII SMP NEGERI 1 PAKUSARI Kecamatan Pakusari Kabupaten Jember.
\end{abstract}

Kata kunci: Media Hullahop, Guling depan dan Guling Belakang, Senam lantai

\section{PENDAHULUAN}

Menurut Achmad Paturusi (2012: 4-5), pendidikan jasmani merupakan suatu kegiatan mendidik anak dengan proses pendidikan melalui aktivitas pendidikan jasmani dan olahraga untuk membantu anak agar tumbuh dan berkembang secara wajar sesuai dengan tujuan pendidikan nasional. Melalui Pendidikan Jasmani, siswa disosialisasikan ke dalam aktivitas jasmani termasuk keterampilan beraktivitas (Adang Suherman, 2000: 1). Menurut Gagne dalam Made Wena (2009: 10), pembelajaran yang efektif harus dilakukan dengan berbagai cara dan menggunakan berbagai macam media pembelajaran. Berdasarkan pendapat di atas sebagai seorang guru wajib kiranya memiliki kiat maupun seni untuk memadukan antara media yang digunakan dan pembelajaran, sehingga pembelajaran yang dihasilkan akan memiliki kualitas atau bobot yang tinggi.

Senam adalah salah satu bagian dari Pendidikan Jasmani. Menurut Imam Hidayat
(2000: 9), senam sebagai suatu latihan tubuh yang dipilih dan dikonstruk dengan sengaja, dilakukan secara sadar dan terencana, disusun secara sistematis dengan tujuan meningkatkan kesegaran jasmani, mengembangkan keterampilan dan menanamkan nilai-nilai mental spiritual. Pengertian senam secara umum merupakan terjemahan dari kata gymnastick atau gymnastiek dalam bahasa Belanda. Gymnastick dalam bahasa Yunani berasal dari kata Gymnis yang berarti telanjang (Agus Mahendra, 2001: 1). Menurut Imam Hidayat dalam Agus Mahendra (2001: 1), gimnastik adalah kegiatan fisik yang memerlukan keluasan gerak. Selanjutnya mengatakan senam adalah suatu latihan tubuh yang dipilih dan dikonstruk dengan sengaja, secara sadar, dan terencana disusun secara keterampilan dan menanamkan nilai-nilai mental spiritual. Peter $\mathrm{H}$ Wenner dalam Agus Mahendra (2001: 3) menjelaskan bahwa senam dapat diartikan sebagai suatu latihan 
tubuh pada lantai atau pada alat yang dirancang khusus untuk meningkatkan daya tahan, kelentutan, kekuatan, kelicahan, koordinasi, dan kontrol tubuh. Jadi fokusnya tubuh bukan alatnya atau gerakannya. entuk senam lantai menurut Agus Mahendra (2001: 44-45) terdiri atas beberapa keterampilan diantaranya: Lenting tengkuk, Lenting kepala (head spring), Gerakan berguling kedepan dilanjutkan lenting tengkuk atau kepala, Berdiri tangan (handstand), Berguling ke belakang diteruskan dengan meluruskan kedua kaki serentak ke atas (back extention), Salto bulat ke depan, dan Meroda (Raslag/cart wheel). Muhajir (2004: 133) berpendapat bahwa "guling ke depan adalah berguling ke depan atas bagian belakang badan (tengkuk, punggung, pinggang, dan pinggul bagian belakang)". Latihan guling ke depan dapat dilakukan dengan dua cara, yaitu: guling ke depan dengan sikap awal jongkok dan guling ke depan dengan sikap awal berdiri. Menurut Berty Tilarso (2000: 1), lebih detail lagi bahwa gerakan guling depan dibagi menjadi beberapa fase mulai dari sikap berdiri kemudian badan diturunkan sehingga menjadi labil dengan cara memindahkan titik berat badan ke depan atau dari kedua kaki ke kedua tangan.

Sedangkan guling kebelakang atau roll belakang menurut Muhajir (2006) adalah mengguling ke belakang, posisi badan tetap harus membulat, yaitu kaki dilipat, lutut tetap melekat di dada, kepala ditundukan sampai dagu melekat didada. Beberapa gerakan tersebut juga diajarkan dalam pembelajaran disekolah dengan menggunakan metode dan medi pembelajaran yang seadanya.

Menurut Sadiman (dalam Depdiknas, 2003: 7), pembelajaran merupakan padanan kata dari istilah instruction, yang mengandung arti lebih luas dari pengajaran. Pembelajaran adalah suatu proses membelajarkan subjek didik yang direncanakan, dilaksanakan, dan dievaluasi secara sistematis agar subjek didik dapat mencapai tujuan pembelajaran secara efektif dan efisien. Pembelajaran tidak hanya terjadi dalam pendidikan (education) tetapi juga dalam pelatihan (training) (Depdiknas, 2003: 7). Pembelajaran adalah usaha sadar guru untuk membantu siswa atau anak didik agar mereka dapat belajar sesuai dengan kebutuhan dan minatnya (Purwanto, 2000:
24). Menurut Rusman (2012:145)"media sebagai arti yang terbatas yaitu sebagai alat bantu pembelajaran". Hal ini berarti media sebagai alat yang digunakan guru untuk memotifasi belaja siswa, memperjelas informasi pembelajaran, memberi tekanan pada bagian-bagian yang penting memberi variasi pembelajaran, memeperjelas sturktur pembelajaran.dengan belajar kita juga bisa bermain, seperti contoh bermain hulahoop.

Pentingnya permainan hulahoop Menurut Faruq (2009:4) Beberapa alasan mendasar mengapa hulahop bisa dianggap penting untuk pengembangan fisik motorik pada anak atau kekayaan pengalaman gerak dan pengembangan kecerdasan gerak (smart move) antara lain: 1). Dengan satu media hulahoop bisa peroleh beragam aktivitas gerak yang menyenangkan bagi anak-anak. 2). Sangat mudah, praktis dan aman penggunaannya. 3). Mempunyai tingkat keselamatan yang relatif lebih aman bagi anak-anak. 4). Dapat dikembangkan dengan berbagai macam aktivitas gerak yang tidak hanya untuk individu, berpasangan tetapi juga berkelompok. 5). Mudah digunakan dan sekaligus dapat mengembangkan berbagai macam gerakan-gerakan yang kreatif shingga ikut membantu mengembangkan kreativitas anak. 6). Bisa digunakan diberbagai tempat diman saja tergantung dan jenis kegiatan yang diinginkan.

\section{METODE}

Penelitian tindakan kelas merupakan cara seseorang untuk mempelajari pengalaman tersebut agar dapat diakses oleh orang lain (Sukardi, 2003). Sedangkan menurut Kunandar (2008) Penelitian Tindakan Kelas merupakan tindakan yang dilakukan oleh guru sekaligus peneliti secara bersamaan untuk merancang, melaksanakan dan merefleksikan tindakan sehingga dapat memperbaiki serta meningkatkan kualitas pembelajaran. Menurut Arikunto (2010) ada empat tahap penting dalam penelitian tindakan, yaitu perencanaan, pelaksanaan, pengamatan dan refleksi. Keempat tahapan penelitian tindakan tersebut adalah membentuk sebuah siklus, jadi satu siklus adalah dimulai dari tahap perencanaan sampai dengan refleksi. Banyaknya siklus tergantung atau tidaknya tindakan tersebut 
dianggap cukup tergantung pada permasalahan pembelajaran yang perlu dipecahkan. Lokasi dan waktu penelitian dilakukan di SMP Negeri 1 Pakusari dengan siswa siswi kelas VII. Subyek penelitian ini adalah seluruh siswa kelas VII SMP Negeri 1 Pakusari tahun ajaran 2018/2019.

Pengumpulan data yang dilakukan pada penelitian ini menggunakan tiga aspek yaitu kognitif, afektif dan psikomotor. Afektif merupakan cara untuk mengetahui sikap pada siswa, kognitif merupakan kemampuan siswa untuk menjawab pertanyaan terhadap aktifitasnya sendiri, sedangkan psikomotor merupakan kemampuan untuk melakukan gerakan atau aktifitas tertentu. Pada penelitian ini menggunakan data secara kuantitatif penyajian data secara kuantitatif perlu dilakukan agar memberikan kejelasan terhadap efektivitas tindakan. Efektivitas tindakan dapat diidentifikasikan pada dua unsur yaitu: (1) adanya peningkatan hasil belajar atau kemampuan anak antar siklus dan, (2) adanya ketercapaian pada indikator penelitian penilaian dilaksanakan selama proses dan sesudah pembelajaran.

\section{HASIL}

Perbandingan Kategori Guling Depan

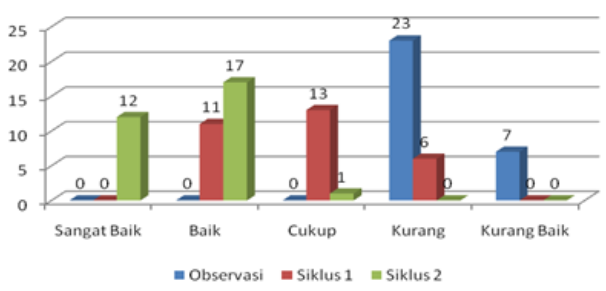

Gambar 1. Perbandingan Kategori Guling Depan

Berdasarkan gambar hasil penelitian senam lantai guling depan. Hasil observasi senam lantai guling depan di atas, pada saat penilaian observasi jumlah siswa yang masuk dalam kategori kurang baik 7 (23\%), kurang $23(77 \%)$, cukup $0(0 \%)$, baik $0(0 \%)$, dan sangat baik $0(0 \%)$. Kemudian pada saat penilaian siklus I jumlah siswa yang masuk dalam kategori kurang baik $0(0 \%)$, kurang 6 (20\%), cukup $13(43 \%)$, baik $11(37 \%)$, dan sangat baik $0(0 \%)$. Dan pada saat penilaian siklus II jumlah siswa yang masuk dalam kategori kurang baik $0(0 \%)$, kurang $0(0 \%)$, cukup $1(3 \%)$, baik $17(57 \%)$, dan sangat baik $12(40 \%)$.
Perbandingan Kategori Guling Belakang

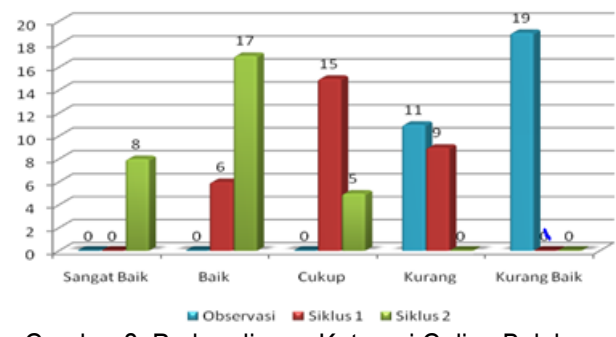

Gambar 2. Perbandingan Kategori Guling Belakang

Berdasarkan gambar hasil penelitian senam lantai guling belakang. Hasil observasi senam lantai guling belakang di atas, pada saat penilaian observasi jumlah siswa yang masuk dalam kategori kurang baik $19(63 \%)$, kurang $11(37 \%)$, cukup $0(0 \%)$, baik $0(0 \%)$, dan sangat baik $0(0 \%)$. Kemudian pada saat penilaian siklus I jumlah siswa yang masuk dalam kategori kurang baik $0(0 \%)$, kurang 9 $(30 \%)$, cukup $15(50 \%)$, baik $6(20 \%)$, dan sangat baik $0(0 \%)$. Dan pada saat penilaian siklus II jumlah siswa yang masuk dalam kategori kurang baik $0(0 \%)$, kurang $0(0 \%)$, cukup $5(17 \%)$, baik $17(56 \%)$, dan sangat baik $8(27 \%)$.

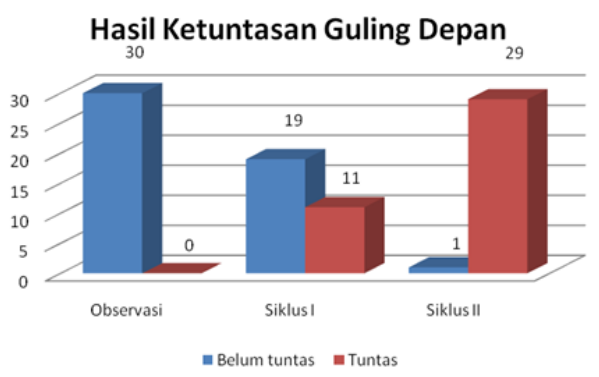

Gambar 3. Hasil Ketuntasan Guling Depan

Berdasarkan gambar diatas dapat dijelaskan bahwa, hasil unjuk kerja senam lantai guling depan menunjukan bahwa siswa yang mencapai KKM minimal (75\%) dari 30 siswa,yaitu pada saat observasi hanya 0 siswa $(0 \%)$ tuntas, 30 siswa $(100 \%)$ belum tuntas. Pada siklus I terjadi peningkatan ketuntasan sebesar (37\%) yaitu siswa tuntas 11 siswa,(63\%) belum tuntas 19 siswa, dan pada siklus II terjadi peningkatan ketuntasan sebesar $(97 \%)$ yaitu siswa tuntas 29 siswa,(3\%) yaitu 1 siswa yang belum tuntas. Dari hasil penelitian ini dapat disimpulkan bahwa tindakan dengan metode pembeljaran senam lantai guling depan menggunakan media hulahoop yang dilakukan dalam 2 siklus terbukti mampu meningkatkan hasil 
pembelajaran pada siswa kelas VIII SMP NEGERI 1 PAKUSARI Kecamatan Pakusari Kabupaten Jember.

Melihat saat observasi siswa kelas VIII SMP NEGERI 1 PAKUSARI seluruh siswa 30 anak $(100 \%)$ yang belum memenuhi KKM. Hal ini di karenakan siswa secara umum kurang menyukai pembelajaran senam lantai guling depan dan masih banyak yang malasmalasan ketika pembeljaran berlangsung.

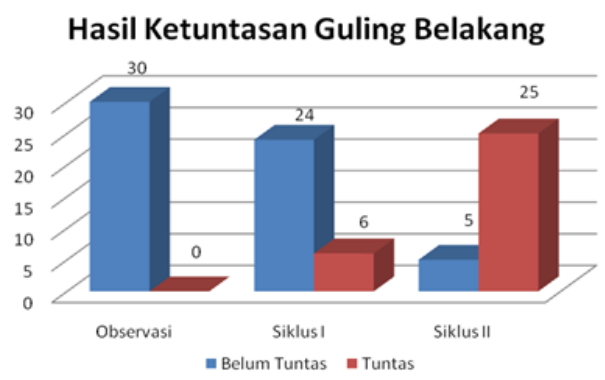

Gambar 4. Hasil Ketuntasan Guling Belakang

Berdasarkan gambar di atas dapat di dijelaskan bahwa, hasil unjuk kerja senam lantai guling belakang menunjukan bahwa siswa yang mencapai KKM minimal $(75 \%)$ dari 30 siswa,yaitu pada saat observasi hanya 0 siswa (0\%) tuntas, 30 siswa $(100 \%)$ belum tuntas. Pada siklus I terjadi peningkatan ketuntasan sebesar $(20 \%)$ yaitu siswa tuntas 6 siswa, $(80 \%)$ belum tuntas 24 siswa, dan pada siklus II terjadi peningkatan ketuntasan sebesar (83\%) yaitu siswa tuntas 25 siswa, $(17 \%)$ yaitu 5 siswa yang belum tuntas. Dari hasil penelitian ini dapat disimpulkan bahwa tindakan dengan metode pembeljaran senam lantai guling belakang menggunakan media hulahoop yang dilakukan dalam 2 siklus, terbukti mampu meningkatkan hasil pembelajaran pada siswa kelas VIII SMP NEGERI 1 PAKUSARI Kecamatan Pakusari Kabupaten Jember.

Melihat saat observasi siswa kelas VIII SMP NEGERI 1 PAKUSARI seluruh siswa 30 anak $(100 \%)$ yang belum memenuhi KKM. Hal ini di karenakan siswa secara umum kurang menyukai pembelajaran senam lantai guling belakang dan masih banyak yang malas-malasan ketika pembelajaran berlangsung.

\section{PEMBAHASAN}

Hasil dari siklus I tampak sudah ada perubahan dari kondisi observasi hal ini bisa di lihat dari siswa yang memenuhi KKM yang awalnya $0(100 \%)$ siswa berubah menjadi 11 siswa (37\%). Dengan adanya media hulahoop anak yang biasanya malasmalasan, sekarang menjadi lebih aktif, penuh semangat untuk beraktivitas tanpa ada paksaan mulai dari awal pembelajaran sampai akhir pembelajaran. Bahkan sampai akhir pembelajaranpun seakan siswa masih tetap ingin melakukannya lagi.

Hasil dari siklus II hasil siswa semakin menunjukkan perkembangan yang baik hal ini bisa di lihat dari siswa yang memenuhi KKM sudah mencapai (97\%) yakni 29 siswa tuntas. Dalam siklus II siswa terlihat semakin aktif dalam melakukan aktivitas pembelajaran. Apalagi permainan yang mereka hadapi saat ini adalah hal yang baru lagi yang lebih menantang. Semangat berkompetisi mereka sangat menggebu-gebu. Bahkan ada yang mencoba sampai berulang kali tanpa disuruh oleh peneliti. Siswa yang masih mendapat nilai dibawah KKM disebabkan karena siswa tersebut kurang konsentrasi, semangat dan kurang menguasai tekhnik yang diberikan dalam melaksanakan senam lantai guling depan. yaitu sebanyak 1 siswa (3\%) belum tuntas pada kondisi awal dan 0 siswa (100\%) dalam siklus pertama.

Hasil dari siklus I tampak sudah ada perubahan dari kondisi observasi hal ini bisa di lihat dari siswa yang memenuhi KKM yang awalnya $0(100 \%)$ siswa berubah menjadi 6 siswa $(20 \%)$. Dengan adanya media hulahoop anak yang biasanya malasmalasan, sekarang menjadi lebih aktif, penuh semangat untuk beraktivitas tanpa ada paksaan mulai dari awal pembelajaran sampai akhir pembelajaran. Bahkan sampai akhir pembelajaranpun seakan siswa masih tetap ingin melakukannya lagi.

Hasil dari siklus II hasil siswa semakin menunjukkan perkembangan yang baik hal ini bisa di lihat dari siswa yang memenuhi KKM sudah mencapai (83\%) yakni 25 siswa tuntas. Dalam siklus II siswa terlihat semakin aktif dalam melakukan aktivitas pembelajaran. Apalagi permainan yang mereka hadapi saat ini adalah hal yang baru lagi yang lebih menantang. Semangat berkompetisi mereka 
sangat menggebu-gebu. Bahkan ada yang mencoba sampai berulang kali tanpa disuruh oleh peneliti. Siswa yang masih mendapat nilai dibawah KKM disebabkan karena siswa tersebut kurang konsentrasi, semangat dan kurang menguasai tekhnik yang diberikan dalam melaksanakan senam lantai guling belakang. yaitu sebanyak 5 siswa $(17 \%)$ belum tuntas pada kondisi awal dan 0 siswa $(100 \%)$ dalam siklus pertama.

\section{DAFTAR PUSTAKA}

Abdul Majid. (2008). Perencanaan Pembelajaran.Bandung: Remaja Rosdakarya.

Achmad Paturusi. (2012). Manajemen Pendidikan Jasmani dan Olahraga. Jakarta: Rineka Cipta.

Adang Suherman. (2000). Dasar-Dasar Penjaskes. Jakarta: Departemen Pendidikan dan Kebudayaan.

Agus Mahendra. (2001). Pembelajaran Senam di Sekolah Dasar. Jakarta: Departemen Pendidikan Nasional.

Anas Sudijono.(2006). Pengantar Statistik Pendidikan. Jakarta: PT Grafindo Persada.

Berty Tilarso. (2000). Sehat dan Bugar Sepanjang Usia Dengan Senam, Semarang: Seminar dan Lokakarya.

BSNP.(2006). Pendidikan Jasmani Olahraga dan Kesehatan.Jakarta: Debdikbud

Depdiknas.(2003). Undang-Undang Republik Indonesia No 20 Tahun 2003 Tentang Sistem Pendidikan Nasional. Jakarta: Sinar Grafika.

Desminta. (2009). Psikologi Perkembangan. Bandung: PT REMAJA ROSDAKARYA.

Dewi Salma Prawiradilaga. (2007). Prinsip Desain Pembelajaran. Jakarta: Rineka Cipta.

Dimyati dan Mudjiono.(2006). Belajar dan Pembelajaran. Jakarta: Rhineka Cipta.

Muhajir. (2016). Pendidikan Jasmani, Olahraga, dan kesehatan. Jakarta: Kemdikbud. 